World Lumen Congress 2021 | May 26-30, 2021 | lasi, Romania

\title{
Social Dimensions of Roma Marginalization
}

\author{
Romana ONET,
}

https://doi.org/10.18662/wlc2021/55

How to cite: Oneț, R. (2021). Social Dimensions of Roma Marginalization. In A. Sandu (vol. ed.), Lumen Proceedings: Vol. 17 World Lumen Congress 2021 (pp. 542-551). Iasi, Romania: LUMEN Publishing House. https://doi.org/10.18662/wlc2021/55 


\title{
Social Dimensions of Roma Marginalization
}

\author{
Romana ONET, ${ }^{1}$
}

\begin{abstract}
The paper aims to analyze aspects of Roma marginalization, by identifying and assessing the dimensions of social needs within a compact Roma community, located in a marginalized urban area.

The effects of the economic crisis and the COVID-19 pandemic increase inequalities regarding the economic and social situation. The major challenge is to reduce the risk of poverty, especially among families with children, people with disabilities and chronic diseases, but also the social exclusion of people at social risk, based on accurate measurements of social phenomena.

The community profile indicates the social status of the inhabitants, which provides a picture of the degree of marginalization and social exclusion of Roma. Thus, the study was conducted by constructing a questionnaire as a research tool, which summarizes the results of the activity of information collection and processing, both based on statistical methods and percentage analysis.

The problems faced by marginalized Roma communities are low participation in education, early school leaving, difficult transition to tertiary education, lack of adult skills, low skills among vulnerable people in the labor market, low access to services, poor health and housing. Measures for early detection of situations of social risk and intervention lead to positive effects in preventing marginalization and social exclusion.
\end{abstract}

Keywords: social dimensions, roma, marginalization, inequalities.

\section{Introduction}

Social marginalization is defined by the peripheral social position, of isolation of individuals or groups with limited access to the economic, political, educational and communication resources of community (Romanian Parliament, 2002). It's about the absence of minimum of social living conditions, limited access to employment, housing, health and education.

At Baia Mare city level there are several marginalized areas, located mainly on the outskirts of neighborhoods with more vulnerable populations,

${ }^{1} \mathrm{PhD}$, Baia Mare, Romania, romana.onet@gmail.com 
which often face situations of social risk, unsanitary living conditions, low employment on the labor market, low level of education, respectively poor health.

The inhabitants of these areas need support measures in order to access living conditions that comply with all provisions related to the accessibility of basic services (education, health, employment, social assistance), utilities of public interest (water, electricity, sewerage), transport infrastructure, including environmental conditions.

Interventions need to take into account all the integrated social needs of the inhabitants of these areas, following complex assessments and analyzes, in order to address issues such as accessibility, education, employment, health or housing.

Measuring social phenomena is likely to create an overview of the marginalization of the inhabitants of these areas. The paper aims to capture the size of the social needs of the marginalized community Pirita, located on the outskirts of Baia Mare, where a compact Roma community lives, in order to design appropriate responses to reduce economic and social inequalities it faces.

\section{Research methodology}

During the '90s, on the outskirts of Baia Mare, residential areas were set up informally by erecting inappropriate constructions, without connections to the networks of public access infrastructure or utilities, by abusive occupation of public or private land, by people without income, mostly belonging to the Roma ethnic group.

The context is common to all informal Roma communities migrating from Eastern Europe created at the same time on the outskirts of Western European cities. The inhabitants of the marginalized areas are former tenants of some public or private houses in Baia Mare, who alienated their right. Subsequently, they were joined by people from other localities of Maramureş County, but also of neighboring counties.

The continuous growth of the population in the peripheral areas has led to the generation of its specific problems: conditions and lifestyle below the poverty line, a state of environment and hygiene that turns into threats to public health.

For focusing the specific needs of vulnerable groups, including Roma, we propose to conduct a needs analysis on an urban marginalised community, namely Pirita. The community was selected based on the following criteria: a compact Roma community, extended territorially, with 
reduced accessibility to basic services; the number of members of the compact Roma community; problems of poverty and social exclusion.

The research was conducted in 2021 on the whole community, composed of 50 households, using quantitative methods through the application of a questionnaire to persons over 18 years old from each household.

The analysis of the needs and constraints faced by the Pirita community in Baia Mare used a multisectoral, integrated approach in the fields of employment, vocational education and training, health, housing and access to social rights.

The questionnaire provides two categories of information: household data (total number of members, their distribution by minor and adult categories, other socio-demographic information about all household members) and data about the respondent (opinions, attitudes, satisfaction with relevant aspects in the study present: housing, medical and sociomedical services, educational services, social issues and information on family dynamics).

The methodology includes the analysis of strategic documents, reports and statistical data.

The main approach of the marginalisation is the integrated approach, according to which, in order to ensure the full potential of the person's social functioning as a full member of the family, community and society, social services must be linked to all the needs of the beneficiary and integrated with a wide range of economic measures and educational, health, cultural services (Romanian Parliament, 2011).

\section{Policy framework on roma marginalisation}

While the Europe 2020 Strategy focused on poverty reduction, "the challenge of reducing the risk of poverty is linked to the inequality debate" (European Commission, 2017). The European pillar of social rights aims combating rising income inequality and ensuring greater equality of opportunities.

Inequalities have become a major problem in recent years, in most European countries, amid the deepening effects of the economic crisis and COVID-19 pandemic, with consequences for social protection systems, economic growth and social cohesion, according to the European Commission (2017). Severe material deprivation rate and the share of socially disadvantaged people are among the most raised in the EU. 
According to the data of the Country Report on Romania "one out of three Romanians is further at risk of poverty or social exclusion, among the most categories exposed counting families with children, the unemployed, inactive people, atypical workers, Roma, elderly women and people with disabilities" (European Commission, 2020b). A percent of $85 \%$ of Roma children are at risk of poverty compared to $20 \%$ of children in the general population (European Commission, 2020b).

Since 2011, the European Commission has adopted an EU framework for national Roma integration strategies until 2020, so that Member States can develop national Roma integration strategies and implement an integrated and sustainable cross-sectoral approach. The economic and social marginalization of the Roma acquires relevance for the Europe 2020 Strategy (European Commission, 2012, pp. 3-12).

At European level, policies in the field of socio-economic integration of Roma and combating social exclusion have focused until 2020 on increasing ,equal access to education, jobs, health and housing” (European Commission, 2020a, pp. 6).

The complexity and interdependance of problems require sustainable responses addressing all aspects of Roma poverty through an integrated approach. The European Commission encourages integrated programming, which combines actions from several operational programs, to support interventions that take an intersectoral approach to addressing issues related to Roma communities (European Commission, 2010, 133, pp. 2-6).

In the field of education, most European countries, including Romania, reported implementing measures to combat early school leaving, examining the needs of each student in cooperation with their families, increasing access to education and care for preschool children, combating illiteracy, encouraging Roma participation and graduating from secondary and tertiary education, supporting the transition between levels of education, supporting the acquisition of skills adapted to the needs of the labor market, promoting extracurricular activities, using teaching methods favorable to inclusion, improving the skills of teachers (European Commission, 2019b, p. 2).

Romania has not registered in recent years progress in the field of facilitating the access of Roma children to early education, although participation subsequently increases the chances of maintaining in the formal education system. The governments utilized ESIF for support in addressing the shortage of kindergartens and teachers (European Commission, 2019a). Three programmes were targeted to reduce the dropout rate for Roma youth, including afterschool education, financial incentives and second chance education (European Commission, 2019a, pp. 210-214). 
In the field of education, there are still major discrepancies between Roma and majority children in terms of school participation, level of school performance and school dropout, as well as regarding the differentiated treatment, both in terms of the quality of the act as well as discrimination and segregation.

The last census in Romania (2011) indicated that the share of majority ethnics who did not graduate from any school was $1 \%$ while the share of Roma ethnics was $14 \%$. Of the total number of people considered illiterate, almost $30 \%$ belong to Roma minority.

Recent research (Romanian Government, 2018, p. 12) shows that two-thirds of Roma ethnics have either not graduated class, or have graduated from high school, a share five times higher than that of the majority. Half of the Roma people that graduated maximum of 8 classes either do not know how to write or have great difficulty writing. In the case of high school graduates, the share of the majority ethnics that completed high school were three times higher than those of Roma ethnics.

Data on the socio-economic situation of the Roma (European Commission, 2011) show that there is a significant gap between the employment rate of the Roma and that of the rest of the population. The EU-MIDIS II report (European Union Agency for Fundamental Rights, 2016) shows that only one in four Roma at least 16 years old is employed or self-employed. A percentage of 63\% of young people aged 16-24 did not have a job and did not participate in any form of education or training activities, with a considerable gap between women and men. The paid employment rates of Roma aged 20-64 were 43\% compared to the EU average of $70 \%$ in 2015 .

In Romania, Roma people's integration on labor market is not approached according to the specific needs of the Roma's at each community level, nor in accordance with their lack of basic skills.

The solutions should take into account the facilitation of nondiscriminatory access of Roma to vocational training, professional training, employment assistance and childcare services. Active inclusion is designed to increase the participation rate of Roma in the labor market, as a combination of measures to access the labor market and social protection.

Health situation of the Roma is worse than average due to socioeconomic conditions, poverty, low screening rates. On EU level, the share of Roma covered by health insurances is $76 \%$ and of those that suffer of a disease or a health problem on long term is $22 \%$ (European Commission, 2019b).

Most of EU states aim at improving Roma's access to medical assistance, extending medical insurance coverage, increasing access to basic, 
emergency and specialized services, informing campaigns on regular medical check-ups, prenatal care, family planning and immunization, preventive sanitary measures, improving living conditions. Regarding health care services, community services provided by community nurses and health mediators will be integrated with educational and social services, in accordance with the needs of the community and its particular profile.

Many Roma live in areas where all their neighbors are Roma, in households without access to water supply, in improvised shelters or in overcrowded households. In Romania, over 60.000 Roma families live in informal housing, on the outskirts of villages and towns (European Commission, 2019b).

Measures for improving the living conditions include nondiscriminatory access to social housing, combating spatial segregation, integrated territorial measures.

Despite the existence of policy and legal frameworks at national and EU level, the marginalization of Roma persists and many of the estimated 10-12 million Roma in Europe continue to face inequalities and socioeconomic exclusion.

\section{The profile of Pirita marginalized community}

The Pirita Community is located on the edge of Baia Mare city, being formed of 50 shelters, not connected to water, but benefiting of an alternative source of drinking water, not connected to electricity, gas, sewage and without access roads toward the community or inside it.

The Community is characterised by a low accessibility to basic services: education, health, employment services on the labor market and an average accessibility to the services of social assistance.

The community is composed of a number of 50 families, respectively 218 people ( $56 \%$ children). The composition of the families indicates that most are made up of two adults and children. The sex distribution of the inhabitants is relatively balanced, with a slightly higher share in favor of men. Depending on age, most are in the 18-35 age group, followed by the 35-65 age group, so a relatively young population. Most of the inhabitants are Roma (91\%), have identity documents and live in consensual unions.

From the perspective of housing, with one exception, all families in the community live in makeshift shelters, without having legal ownership of the land or building. There is access in the area to an alternative source of drinking water, but the houses are not connected to utilities. 
As for the perception of the inhabitants of Pirita on their own health state, most of them consider it to be pretty good and very good, declaring they are not suffering from chronic diseases or disabilities. Most adults are enrolled in the family doctor, more than half with health insurance. In most cases, the inhabitants have resorted in the last 6 months to consultations at the medical office, prescription of medicines and medical analyzes.

Some of the community members also accessed social assistance services, respectively social benefits, family planning services and psychological counseling. None of the inhabitants requested / received legal assistance for solving the housing situation, obtaining identity documents or being classified as disabled.

Asked about the need for social services, many of those surveyed said they would need a day center for children, support services for single mothers, victims of domestic violence, children (speech therapy), people with disabilities and young people.

The facilities related to the participation in education of children, young people, respectively adults who left school early are known by the community members, respectively the school type programs after school and the second chance.

Most children are after the age of 6-11 years, corresponding to the primary school cycle, followed by preschool and kindergarten children and then by middle school children. Regarding the degree of participation / attendance of the school, about half of them are present at the formal educational activities. Community members benefited from programs such as horn and milk, school supplies, the social scholarship and the merit scholarship.

Many young people aged between 15 and 24 are not enrolled in school and are not employed. Also, most members of the community are people over 18 who have not been enrolled in school $(62 \%)$ and have not completed compulsory education of 10 grades $(23 \%$ have primary school and $9 \%$ have high school).

Very few members of the community are employed full time, being frequent situations of housewives or day workers. Most have occupations in the field of waste collection, city cleaning, constructions, skilled and unskilled workers.

Many do not have qualifications, and those who have are in the fields of confectioner, tailor, mechanical locksmith. The respondents would like to follow professional training courses, because they consider that there are jobs, but they do not have the necessary training to fill them. 
The main incomes of households consist of child allowances, social assistance, occasional income, while most expenses are directed towards food, clothing and children's education.

\section{The needs and constraints in Pirita marginalized community}

Vulnerable groups living in marginalized urban areas face difficulties regarding accessing education, low level of education and training, low participation on formal labor market and shortage on incomes, poor living conditions, lack of access to public utilities and basic services.

The inhabitants of Pirita community pointed need of day center for children, support services for single mothers, victims of domestic violence, children and young people.

\section{Conclusions}

The inhabitants of marginalized urban areas face multiple deprivations, situations of marginalization and social exclusion, constraints related to the socio-professional inclusion. Roma people from the cathegories of unemployed persons, families with one parent, persons with low income or without sources of income live in precarious conditions, with reduced access to public utilities, having a low degree of education, lack of occupational skills and competences and difficulties in accessing formal labor market.

Measures for early detection of situations of social risk and intervention lead to positive effects in preventing marginalization and social exclusion. The role of the authorities is to facilitate access to basic community services, as in the absence of alternatives for socio-professional integration, opportunities to improve health, adequate living conditions and participation in initial and continuing education, the social inclusion of vulnerable people cannot be achieved.

\section{References}

European Commission. (2010). Social and economic integration of the Roma in Europe.https://eur-lex.europa.eu/legalcontent/EN/TXT/PDF/?uri=CELEX:52010DC0133\&from=en

European Commission. (2011). An EU Framework for National Roma Integration Strategies up to 2020. https://eur-lex.europa.eu/legal- 


\section{content/EN/TXT/HTML/?uri=CELEX:52011DC0173\&from=R \\ $\underline{\mathrm{O}}$}

European Commission. (2012). National Roma integration strategies: a first step in implementing the EU framework. https:// eur-lex.europa.eu/legalcontent/EN/TXT/PDF/?uri=CELEX:52012DC0226\&from=EN

European Commission. (2017). European Semester - Fact sheet. Combating inequalities.

https://ec.europa.eu/info/sites/default/files/file import/europeansemester thematic-factsheet addressing-inequalities en $0 . p d f$

European Commission. (2019a). Roma inclusion measures reported under the EU

Framework for NRIS. https://eur-lex.europa.eu/legalcontent/EN/TXT/DOC/?uri=CELEX:52019SC0320\&from=EN

European Commission. (2019b). Report on the implementation of national Roma integration strategies. https: / eur-lex.europa.eu/legalcontent/EN/TXT/PDF/? uri $=$ CELEX:52019DC0406\&from $=E N$

European Commission. (2020a). A new EU Roma strategic framework https://ec.europa.eu/info/sites/default/files/factsheet a new eu roma strategic framework en.pdf

European Commission. (2020b). Country Report - Romania. https://eurlex.europa.eu/legalcontent/EN/TXT/PDF/?uri=CELEX:52020SC0522\&from=EN

European Union Agency for Fundamental Rights. (2016). EU-MIDIS II. Al doilea sondaj privind minoritatile si discriminarea in Uniunea Europeana. Romii- rezultate selectate [EU-MIDIS II. The second survey on minorities and discrimination in the European Union. Roma selected results]. https://fra.europa.eu/sites/default/files/fra uploads/fra-2016-euminorities-survey-roma-selected-findings ro.pdf

Romanian Census. (2011). http://www.recensamantromania.ro/rezultate-2/ Romanian Government. (2018). Strategia Guvernului Romaniei de incluriune a cetatenilor romani apartinand minoritatii rome pentru perioada 2021-2027 [The Romanian Government's strategy for the inclusion of Romanian citizens belonging to the Roma minority for the period 2021-2027].

http://sgglegis.gov.ro/legislativ/docs/2020/11/152nftks6zbd3vpw8 jr.pdf

Romanian Parliament. (2002). Legea Nr. 116 din 15 martie 2002 privind prevenirea și combaterea marginalizării sociale publicata in Monitorul Oficial 
193 din 21 Martie 2002 [Law 116/2002 on preventing and combating social marginalization, published in the Official Monitor no. 193 of March 21, 2002].

https://legislatie.just.ro/Public/DetaliiDocumentAfis/34645

Romanian Parliament. (2011). Legea asistentei sociale, nr. 292 din 20 decembrie 2011 publicata in Monitorul Oficial nr. 905 [Law 292/2011 of social assistance, Romanian Parliament, published in the Official Monitor no. 905 of December 20, 2011].

http://legislatie.just.ro/Public/DetaliiDocument/133913 